PRACE NAUKOWE UNIWERSYTETU EKONOMICZNEGO WE WROCLAWIU

\title{
Wojciech Kisiala
}

Poznań University of Economics and Business

e-mail: wojciech.kisiala@ue.poznan.pl

\section{SPATIAL CROSS-REGRESSIVE MODELS \\ IN THE STUDY OF THE SPATIAL DIFFUSION OF INNOVATION IN CENTRAL EUROPE}

\section{MODELE REGRESJI KRZYŻOWEJ \\ W BADANIU PRZESTRZENNEJ DYFUZJI INNOWACJI W EUROPIE ŚRODKOWEJ}

DOI: $10.15611 / \mathrm{pn} .2017 .476 .09$

JEL Classification: C31, C32, O18, O31, O47

\begin{abstract}
Summary: In the paper, spatial cross-regressive models were used for the identification of the processes of the spatial diffusion of innovations in Central Europe. As it is difficult to measure the diffusion of innovations directly, the empirical part of the work was based on symptomatic indicators. In the course of the research, the author undertook to show how variables indicating the level of innovation (considered to be independent variables) shaped the efficiency of work, expressed as the indicator of gross value added per worker (modelled dependent variable). The regression analysis conducted showed that there was a statistically significant link between innovation and the efficiency of work in Central European countries, also in the dimension of spatial interactions among regions. Econometric modelling led to the conclusion that the spatial diffusion of innovations occurred.
\end{abstract}

Keywords: diffusion of innovation, spatial econometrics, spatial cross-regressive models, NUTS2 regions, Central Europe.

Streszczenie: W artykule modele regresji krzyżowej wykorzystano do identyfikacji procesów przestrzennej dyfuzji innowacji w regionach Europy Środkowej. Ze względu na trudności bezpośredniego pomiaru dyfuzji innowacji empiryczną część pracy oparto na miarach symptomatycznych. W badaniu starano się wykazać, w jaki sposób zmienne określające poziom innowacyjności (traktowane jako zmienne objaśniające) kształtują wydajność pracy, wyrażoną w postaci wskaźnika: wartość dodana brutto/pracujący (modelowaną zmienną objaśnianą). Przeprowadzona analiza regresyjna wykazała, że w regionach Europy Środkowej występował istotny statystycznie związek pomiędzy innowacyjnością a wydajnością pracy, również $\mathrm{w}$ wymiarze przestrzennych interakcji pomiędzy regionami. Modelowanie ekonometryczne pozwoliło domniemywać, że zachodziła przestrzenna dyfuzja innowacji.

Słowa kluczowe: dyfuzja innowacji, ekonometria przestrzenna, modele regresji krzyżowej, regiony NUTS2, Europa Środkowa. 


\section{Introduction}

For years, innovation processes have been the subject of the interest of economists, who have been making attempts to explain the determinants and mechanisms of the economic growth. The significance of innovation results from the growing role of knowledge and information in today's economy. The ability to create, apply and disseminate knowledge is conducive to numerous inventions in the form of not only new products and technologies, but also new ideas, manners of action, types of organisation, and management methods. New solutions, which were created following the adoption, adaptation and application of inventions, are referred to as innovations. They contribute to the growth in the productivity of the classical factors of production (land, labour and capital) and to the construction of so-called knowledge-based economy.

From the point of view of spatial analyses, what has acquired fundamental importance is the issue of the transfer, influence and dissemination of innovation. It has been observed that in the social and economic sphere, innovation processes spread in the same way as particles or energy in the diffusion process analysed in physics. Thus, the spatial diffusion of innovation consists in the dissemination and adaptation of innovative ideas, concepts, products and technologies in a specific geographical space. This process has its time dimension, which means that there are lags in the spread of innovation to other areas. The diffusion of innovation takes place through various distribution channels, which include, among others, the purchase of innovative investment goods, trade agreements concerning intellectual property rights (patents, licences) or direct foreign investment [Firszt 2015].

The issue of the spatial diffusion of innovation has a long tradition in the geographical and economic literature. Pioneering works in this field were written as early as in the 19th century [Ratzel 1891]. However, it was in the second half of the 20th century that the most dynamic development of the studies of diffusion in space occurred. Among the researchers who contributed to this rapid growth were Hägerstrand [1952; 1967], Haggett [1965; 1972], Morrill [1968; 1970], and Rogers [1962]. At present, this field of interest belongs to the canon of theories analysing the territorial dimension of the processes of social and economic development. The issues of spatial diffusion may be found both in the traditional neoclassical models of economic growth and in the models of so-called modern economic geography. An extensive overview of the results of research into the diffusion of innovation is available in the works of, among others, Kamiński [1982], Gomułka [1998], and Brzozowski and Kubielas [2007].

The aim of this work is to identify the processes of the spatial diffusion of innovation in Central Europe by estimating and verifying spatial cross-regressive models (SCM). As it is difficult to measure the diffusion of innovation directly, symptomatic indicators were applied, which take into account the spatial differentiation of work efficiency. Changes in the efficiency of work were seen as a 
potential economic effect of the spread of innovation. The application of crossregressive models allowed for the verification the hypothesis concerning the influence of the level of innovation of neighbouring units on the efficiency of work in the regions under study. The confirmation of this hypothesis may be related to the occurrence of the spatial diffusion of innovation.

The spatial scope of the research includes NUTS2 regions in Central European countries, such as: Poland, the Czech Republic, Slovakia, Hungary, Austria and Germany. The set of 82 regions examined comprises not only highly developed areas of the so-called old European Union, but also the catching-up regions of new member states. The analysis spans the period from 2009 to 2014. All data necessary for the empirical research were obtained from the public Eurostat bases.

\section{The spatial diffusion of innovation from a theoretical perspective}

In the sphere of regional studies, the process of innovation diffusion is associated with the impact of development impulses from well-developed cities and regions both on their neighbouring areas and on more distant ones. The cities and regions in which new products are made, advanced technologies are used, and investments made in research and development, are considered to be the places from which innovation diffuses to the outside [Domański 2012]. The mechanism of diffusion manifests itself in two ways. On the one hand, it may be based on the adaptation of solutions from technologically advanced regions in underdeveloped areas. In this case, the diffusion of innovation, taking the form of the expansion of new solutions to other regions, is the result of the high cost of the creation of own innovations. Poorer regions cannot afford to spend large amounts of money on research and development activity, which is the prerequisite for moving up to a different technology. When they want to enter the path of dynamic development, they adapt inventive products, technologies or organisational and management models, which have already been implemented somewhere else. The ability to absorb innovative solutions largely determines the spatial diversity of the level of the economic development of cities and regions.

On the other hand, in the prosperous units which generate innovation, with time, growth limitations begin to appear. They are connected with, among other things, the scarcity of new land for construction, difficult access to public infrastructure and facilities, and environmental pollution. At the same time, the investment attractiveness of less developed areas increases, which results in the relocation of innovation to poorer regions. In this way, new innovation-generating centres are established and the technological and economic growth spreads.

The situations discussed above refer to two basic types of spatial diffusion: expansion diffusion and relocation diffusion. Expansion diffusion occurs when the transmission is from one place to neighbouring places, and a given phenomenon (e.g. innovation) successively spreads and covers more territorial units. In the case 
of relocation diffusion, the analysed phenomenon clearly changes its location in space, "abandoning" its original place and moving to new locations [Łoboda 1974, Parysek 2001].

Moreover, as regards the nature of the diffusion process, contagious diffusion and hierarchical diffusion can be distinguished. In the case of the former, the process of spreading is of a decentralising character and depends on the direct neighbourhood of the transmitting unit and the absorbing one. What has a significant impact on the course of diffusion is distance since the shorter distance between units in space is, the higher the likelihood of interaction between them becomes. Hierarchical diffusion has a different nature as the spread takes place within the framework of a certain hierarchical spatial or social structure. It begins in the main centres (the biggest and most important in the structure), then it moves to secondary centres, and finally reaches the centres of the lower level in the hierarchy. Diffusion takes place both horizontally (between centres of the same level), and, with some delay, vertically (from a given centre to centres of a lower hierarchical level in the area influenced by it) [Cliff et al. 1981; Parysek 2001; Lewandowska-Gwarda, Antczak 2010; Domański 2012].

The course of the innovation process in time is well illustrated by an S-curve (Figure 1A). In the beginning, the number of absorbers grows slowly. With time and with the growth of origins, the process of diffusion accelerates and the number of followers increases faster. At the last stage, due to difficulties in reaching cells which are the least susceptible to adopt innovation, the dynamics of recipients falls and the pace of the process slows down again [Domański 2013].

The process of diffusion in space may in turn be described in the form of a fourstep model of innovation waves as proposed by Hägerstrand [1952] (Figure 1B). At
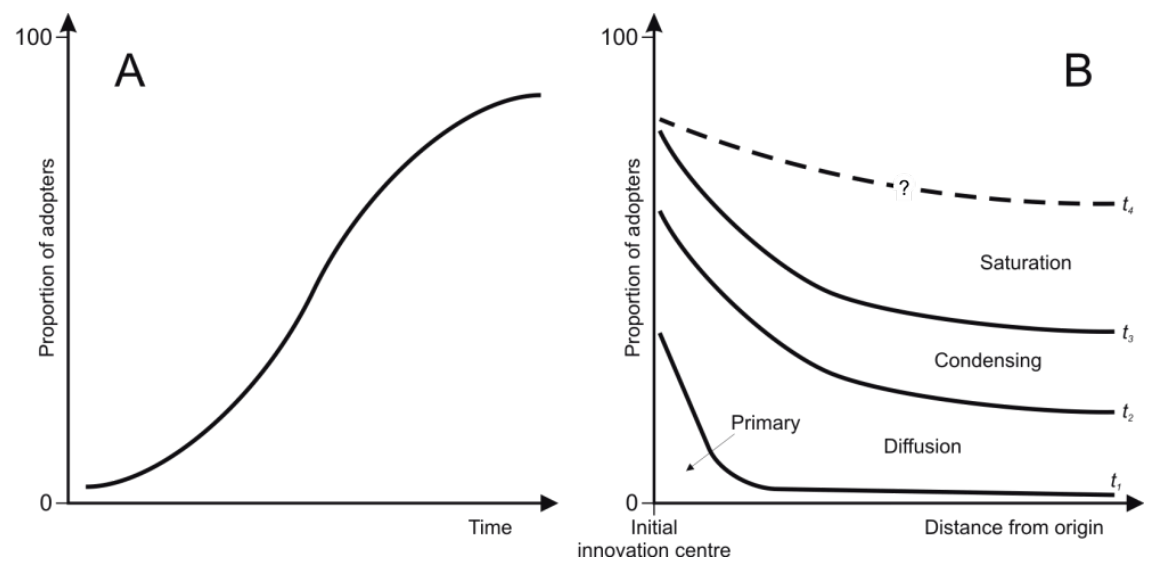

Fig. 1. The course of the process of innovation diffusion in time (A) and space (B)

Source: own work on the basis of Hägerstrand [1952]. 
the primary stage, the biggest number of the recipients of innovation concentrates around the centres that initiate innovation and the bigger the distance from these centres the smaller the number becomes. Then, at the stage of diffusion, the number of followers increases especially in the neighbouring areas, and moderately in the areas more distant from the innovation centres. Owing to this, the significant differences in the structure of absorbers between the centre and more distant areas are reduced. At the condensing stage, through the systematic increase in the number of recipients in the peripheral areas, the proportion of adopters begins to even out in all parts of space. Finally, in the last phase, called the saturation stage, the dynamics of the spatial diffusion of innovation significantly slows down, and the whole process may even terminate [Hägerstrand 1952; Łoboda 1974].

\section{The research procedure}

The theoretical aspects of the processes of innovation diffusion discussed above refer only to specific simplified, model assumptions. In reality, this process is a lot more complex and its quantification is extremely difficult. The diffusion of innovation takes place according to a great many mechanisms, and the pace and intensity of the spread of new ideas, products and technologies differ across regions. It is a consequence of the unequal distribution of population and differences in the quality of human capital and technical devices, which determine entities' capability of absorbing innovation.

The modelling of innovation diffusion is additionally impeded by the lack of statistical data which would comprehensively describe the complexity of the analysed process. That is why the empirical part of the paper was based on symptomatic measures reflecting the potential economic effects of the dissemination of innovation. It was assumed that innovation and technological advancement result in the development of technical devices, growth of productivity, better organisation and conditions of work and in the improvement of the qualifications of employees, which in turn affect work efficiency. Thus, the focus of the research was to find out how variables determining the level of innovation (independent variables) shaped work efficiency, expressed as the indicator of gross value added per worker (dependent variable).

In accordance with the empirically proven rule that the intensity of innovation diffusion is the function of distance and the probability of diffusion between the transmitter and the recipient increases as the distance between them decreases, the research procedure was based on econometric-spatial modelling. Models of spatial econometrics take into consideration, among other things, specific relations between objects, which are the result of their location. Therefore, they make it possible to analyse the influence of adjacent locations on a given object. The specification of spatial econometrics models consists in adding new elements, i.e. spatially lagged variables, to the classical regression equation. 
Among a wide array of spatial models it was the cross-regressive model that was deemed to be the most adequate for the processes of the diffusion of innovation. These models are applied when there are spatial interactions in the set of independent variables and they allow for the determination of how the values of exogenous variables observed in the same and different locations influence the course of a given phenomenon. The identification of the statistically significant impact of the innovation level in neighbouring areas on work efficiency in the region under study was associated with the occurrence of the processes of spatial diffusion.

The SCM model takes the following form in matrix notation:

$$
\mathrm{y}=\mathrm{X} \beta+\gamma \mathrm{WX}+\varepsilon,
$$

where $y$ is the vector $n \times 1$ of the value of the dependent variable, $X$ is the matrix $n \times k$ of the value of independent variables, $\varepsilon$ is the vector $\mathrm{n} \times 1$ of random factors, $\mathrm{W}$ represents the matrix of spatial weights, and $\gamma$ is the estimation of the spatial regression parameter and determines the influence of the value of independent variables from neighbouring locations (in accordance with the established form of the matrix of spatial weights) on the value of the dependent variable in a given location [Suchecki 2010].

Spatial weights necessary for the estimation of models were established with the use of the neighbourhood matrix based on the adjacency of objects. The neighbourhood matrix was subject to standardisation by rows, owing to which the sum of the weights of neighbours for each object was always the same (equal to 1).

As it was mentioned earlier, work efficiency as measured with the GVA per worker indicator (in Euro) was adopted as the dependent variable. The set of independent variables was in turn created on the basis of indicators characterising regions in categories related to innovation and the level of scientific and technological development. The potential independent variables that showed the innovation potential of regions included: $\mathrm{x}_{1}-$ total intramural $\mathrm{R} \& \mathrm{D}$ expenditure (Euro per inhabitant); $x_{2}-R \& D$ expenditure ( $\%$ of GDP); $x_{3}-R \& D$ personnel ( $\%$ of total employment); $\mathrm{x}_{4}$ - patent applications to the EPO (number per million inhabitants); $\mathrm{x}_{5}$ - persons employed in NACE Rev.2 section: $\mathrm{J}$ - information and communication and $\mathrm{M}$ - professional, scientific and technical activities (\% of total employment); $\mathrm{x}_{6}$ - number of local units in NACE Rev. 2 section: $\mathrm{J}$ - information and communication and $\mathrm{M}$ - professional, scientific and technical activities (units per 10000 inhabitants); $\mathrm{x}_{7}-$ persons with tertiary education ( $\%$ of total population); $\mathrm{x}_{8}-$ persons employed in science and technology ( $\%$ of active population).

Moreover, for each independent variable the spatial lag was calculated as the weighted average (according to the adopted matrix of spatial weights) of the value of this variable in neighbouring areas.

The independent variables were eliminated in two stages. First, with the application of the study of graphs [Goryl et al. 2009], interdependent (mutually correlated) variables were removed from the examined set. In the final stage, using 
the stepwise regression procedure, the variables that did not meet the criteria of statistical significance were eliminated.

On account of the space-time nature of the processes of the diffusion of innovation, time shifts were used in modelling - one-year $\left(\mathrm{Y}_{2014} \leftarrow \mathrm{X}_{2013}\right)$, three-year $\left(\mathrm{Y}_{2014} \leftarrow \mathrm{X}_{2011}\right)$ and five-year $\left(\mathrm{Y}_{2014} \leftarrow \mathrm{X}_{2009}\right)$ shifts. Additionally, a model based on dynamics indicators was estimated $\left(\mathrm{Y}_{2014 / 2009} \leftarrow \mathrm{X}_{2013 / 2009}\right)$. In this way, it was determined how changes in the level of innovation translated into changes in work efficiency in regions.

\section{Results}

The regression analysis showed that there was a statistically significant link between the level of innovation and work efficiency in Central Europe, also in the dimension of spatial interactions between regions. The SCM models estimated with the application of the method of least squares were relatively well fitted to the empirical data. The coefficients of determination R2 were from 0.88 to 0.55 , and the other diagnostic measures met the criteria of statistical significance or acceptability, as suggested in the literature. The detailed results of the final models are shown in Table 1.

Table 1. The detailed results of the final estimations of $\mathrm{SCM}(\mathrm{N}=82)$

\begin{tabular}{|l|l|l|l|l|}
\hline \multicolumn{1}{|c}{$\begin{array}{c}\text { Variables and } \\
\text { statistical } \\
\text { measures }\end{array}$} & \multicolumn{1}{|c|}{$\mathrm{Y}_{2014} \leftarrow \mathrm{X}_{2013}$} & \multicolumn{1}{|c|}{$\mathrm{Y}_{2014} \leftarrow \mathrm{X}_{2011}$} & \multicolumn{1}{|c|}{$\mathrm{Y}_{2014} \leftarrow \mathrm{X}_{2009}$} & $\mathrm{Y}_{2014 / 2009} \leftarrow \mathrm{X}_{2013 / 2009}$ \\
\cline { 2 - 6 } & Coeff. $(p$-value $)$ & Coeff. $(p$-value) & Coeff. $(p$-value) & Coeff. ( $p$-value $)$ \\
\hline Intercept & $-40,140.2(0.000)$ & $-35,814.5(0.000)$ & $6,872.9(0.209)$ & $42.656(0.001)$ \\
\hline $\mathrm{x}_{1}$ & $\hat{\beta}=8.3(0.000)$ & $\hat{\beta}=10.2(0.000)$ & $\hat{\beta}=15.5(0.000)$ & $\hat{\beta}=0.062(0.000)$ \\
\hline $\mathrm{x}_{4}$ & - & - & - & $\hat{\beta}=0.057(0.000)$ \\
\hline $\mathrm{x}_{8}$ & $\hat{\beta}=824.5(0.000)$ & $\hat{\beta}=722.7(0.000)$ & $\hat{\beta}=653.0(0.001)$ & $\hat{\beta}=0.394(0.000)$ \\
\hline $\mathrm{x}_{1}$-lag & $\hat{\gamma}=6.8(0.045)$ & $\hat{\gamma}=8.4(0.025)$ & $\hat{\gamma}=26.1(0.000)$ & $\hat{\gamma}=0.074(0.013)$ \\
\hline $\mathrm{x}_{4}$-lag & - & - & - & $\hat{\gamma}=0.053(0.012)$ \\
\hline $\mathrm{x}_{8}$-lag & $\hat{\gamma}=1,609.5$ & $\hat{\gamma}=1,614.6$ & - & - \\
\hline $\mathrm{R} 2 /$ adjusted R2 & $0.8751 / 0.8686$ & $0.8569 / 0.8494$ & $0.8015 / 0.7938$ & $0.5489 / 0.5193$ \\
\hline F-test (p-value $)$ & $134.85(0.000)$ & $115.23(0.000)$ & $104.97(0.000)$ & $18.498(0.000)$ \\
\hline
\end{tabular}

Source: own calculations.

The first two models (with one-year and three-year time lags) had a similar structure. They show that the explained part of the variability of the GVA per worker was determined by expenditure on research and development $\left(\mathrm{x}_{1}\right)$ and the proportion 
of workers in sectors connected with science and technology $\left(\mathrm{x}_{8}\right)$, and the direction of the influence of these variables was positive. Moreover, the dependent variable was stimulated by the spatial lags of variables $\mathrm{x}_{1}$ and $\mathrm{x}_{8}$. This means that the level of innovation in a given region (as measured with its expenditure on R\&D and the number of people performing innovation activities) contributed to the growth in work efficiency not only in this area, but also in its neighbouring regions. This situation might have been the result of the flow of information, products and technologies as part of the process of the diffusion of innovation.

The estimation of the model with the longest (five-year) lag indicates that in the longer term, the spatial lag of $\mathrm{x}_{8}$ variable ceased to be statistically significant for the level of work efficiency. Thus, a hypothesis can be formulated that it is the consequence of the fact that the diffusion process entered subsequent stages and innovation spread to more distant areas. This hypothesis can be verified by constructing a different matrix of spatial weights, which identifies the consecutive neighbourhood rows (the matrix of spatial weights in the estimated models took into consideration only the closest, direct neighbours).

The model which assesses the relations between the indicators of dynamics of particular variables proves, in turn, that the percentage changes of the GVA per worker were connected with the relative growth of such indicators as R\&D expenditure $\left(\mathrm{x}_{1}\right)$, patent applications $\left(\mathrm{x}_{4}\right)$, and employment in science and high technologies $\left(\mathrm{x}_{8}\right.$ ), and, additionally, of the spatial lags of variables $\mathrm{x}_{1}$ and $\mathrm{x}_{4}$. The modelling of the dynamics of the examined phenomena once again allowed for the assumption that the spatial diffusion of innovation occurred in the time and space under study. Changes in the level of innovation in different regions led to the improvement of the situation of a larger area, and development impulses were observed in the neighbouring regions.

The symptomatic nature of the estimated relations calls for cautiousness when expressing unanimous opinions regarding the occurrence of the diffusion process. The identified regularities, however, may constitute the basis for in-depth research both into the identification of the intensity of innovation diffusion and into its space and time scope.

\section{Conclusion}

The cross-regressive models applied in the paper enabled the verification of usefulness of the methods of spatial econometrics in modelling the processes of the diffusion of innovation. The statistically significant estimates of the spatial lags of variables representing the level of innovation in regions are a proof of the effectiveness of the process of diffusion and their adaptation by the regions of Central Europe. The identified spatial interactions and the established influence of the level of innovation on the development of work efficiency confirm the views - present in the literature - that when discussing the determinants of the social and economic development, 
particular emphasis should be put on innovation processes, with their characteristic time- and place-specific mode of spreading, referred to as the diffusion of innovation.

The simplifying assumptions in the adopted research procedure allowed for the presentation of the innovation diffusion mechanism more clearly. In order to take account of the complexity of the analysed process, in-depth studies in the field of econometrics and spatial statistics are required. What is particularly recommended is the specification of different matrixes of spatial weights and the application of alternative ways of weighting in accordance with the knowledge concerning spatial and time aspects of the diffusion process and relations between the examined regions.

\section{References}

Brzozowski M., Kubielas S., 2007, Struktura techniczna gospodarki a dyfuzja technologii w perspektywie konwergencji realnej Polski z UE, [in:] J.J. Michałek, W. Siwiński, M.W. Socha (eds.), Polska w Unii Europejskiej. Dynamika konwergencji ekonomicznej, Wyd. Nauk. PWN, Warszawa, pp. 68-97.

Cliff A.D., Haggett P., Ord J.K., Versey G.R., 1981, Spatial Diffusion. An Historical Geography of Epidemics in an Island Community, Cambridge University Press, Cambridge.

Domański R., 2012, Ewolucyjna gospodarka przestrzenna, Wyd. Uniwersytetu Ekonomicznego w Poznaniu, Poznań.

Domański R., 2013, Gospodarka przestrzenna. Podstawy teoretyczne, Wyd. Nauk. PWN, Warszawa.

Firszt D., 2015, Dyfuzja innowacji i konwergencja technologiczna, [in:] Ł. Jabłoński (ed.), Konwergencja, kapitat ludzki, innowacje. Polska w perspektywie porównawczej, CeDeWu, Warszawa, pp. 45-64.

Gomułka S., 1998, Teoria innowacji i wzrostu gospodarczego, CASE, Warszawa.

Goryl A., Kukuła K., Walkosz A., 2009, Modele jednorównaniowe liniowe, [in:] K. Kukuła (ed.), Wprowadzenie do ekonometrii, Wyd. Nauk. PWN, Warszawa.

Haggett P., 1965, Locational Analysis in Human Geography, Edward Arnold, London.

Haggett P., 1972, Geography: a Modern Synthesis, Harper \& Row Publishers, New York.

Hägerstrand T., 1952, The Propagation of Innovation Waves, Lund Studies in Geography, Ser. B, no. 4, Royal University of Lund, London.

Hägerstrand T., 1967, Innovation Diffusion as a Spatial Process, The University of Chicago Press, Chicago-London.

Kamiński Z., 1982, Przestrzenna dyfuzja innowacji rolniczych, Wyd. Nauk. UAM, Poznań.

Lewandowska-Gwarda K., Antczak E., 2010, Nowa ekonomiczna geografia i modele specjalne, [in:] B. Suchecki (ed.), Ekonometria przestrzenna. Metody i modele analizy danych przestrzennych, Wyd. C.H. Beck, Warszawa, pp. 202-236.

Łoboda J., 1974, Niektóre geograficzne problemy dyfuzji innowacji, Przegląd Geograficzny, Vol. XLVI, no. 2, pp. 243-262.

Morrill R.L., 1968, Waves of spatial diffusion, Journal of Regional Science, Vol. 8, no. 1, pp. 1-18.

Morrill R.L., 1970, The shape of diffusion in space and time, Economic Geography, Vol. 46, pp. 259-268.

Parysek J.J., 2001, Podstawy gospodarki lokalnej, Wyd. Nauk. UAM, Poznań.

Ratzel F., 1891, Anthropogeographie: die geographische Verbreitung der Menschen, Stuttgart.

Rogers E.M., 1962, Diffusion of Innovations, Free Press, New York.

Suchecki B., 2010, Modele regresji przestrzennej, [in:] B. Suchecki (ed.), Ekonometria przestrzenna. Metody i modele analizy danych przestrzennych, Wyd. C.H. Beck, Warszawa, pp. 237-266. 